\title{
Understanding a Culturally Diverse World
}

Citation for published version (APA):

Peterson, M. F. (2006). Understanding a Culturally Diverse World. Datawyse.

https://doi.org/10.26481/spe.20060601mp

Document status and date:

Published: 01/06/2006

DOI:

10.26481/spe.20060601 mp

Document Version:

Publisher's PDF, also known as Version of record

\section{Please check the document version of this publication:}

- A submitted manuscript is the version of the article upon submission and before peer-review. There can be important differences between the submitted version and the official published version of record.

People interested in the research are advised to contact the author for the final version of the publication, or visit the DOI to the publisher's website.

- The final author version and the galley proof are versions of the publication after peer review.

- The final published version features the final layout of the paper including the volume, issue and page numbers.

Link to publication

\footnotetext{
General rights rights.

- You may freely distribute the URL identifying the publication in the public portal. please follow below link for the End User Agreement:

www.umlib.nl/taverne-license

Take down policy

If you believe that this document breaches copyright please contact us at:

repository@maastrichtuniversity.nl

providing details and we will investigate your claim.
}

Copyright and moral rights for the publications made accessible in the public portal are retained by the authors and/or other copyright owners and it is a condition of accessing publications that users recognise and abide by the legal requirements associated with these

- Users may download and print one copy of any publication from the public portal for the purpose of private study or research.

- You may not further distribute the material or use it for any profit-making activity or commercial gain

If the publication is distributed under the terms of Article $25 \mathrm{fa}$ of the Dutch Copyright Act, indicated by the "Taverne" license above, 


\section{Understanding a \\ Culturally Diverse World}




\section{Colotion}

Basisontwenp en reabigatie oce Business Services, Uniwersiteit Maostricht.

$150 N 90-5681 \cdot 241+6$

NUR 780

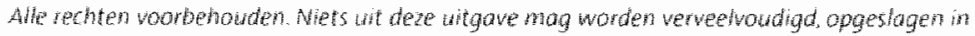

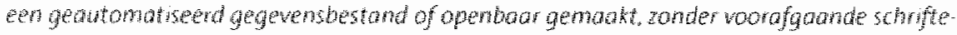
Jike roestemming van de auter of witgever. 


\section{Understanding a Culturally Diverse World}

\section{Lecture}

for the Opening Ceremonies of the Hof stede Chair in Cultural Diversity, University of Mastricht. The Netherlands

on Friday, lune 151, 2006

by

Mark F. Peterson

University of Mastricht

Florida Atlantic University

tis 

Establishing the Hofstede Chair in Cultural Diversity at the University of Masstricht is significant in several ways. Having the Chair in the city of Maastricht is significant because of the historical role that the city has had in the development of a supranational entity as culturally diverse as is the European Union. Naming the Chair in honor of Professor Hofstede is significant because his work marks a major transition in the history of social thought about cultural diversity.

These two characteristics of the Chair mark a need and a direction for meeting it. The Treaty of Maastricht exemplifies the need for understanding a culturally diverse world - the degree of interaction between different cultures continues to increase at the national, organizational, and interpersonal levels. Professor Hofstede's work takes a step in the right direction toward meeting that need by providing a framework for understanding the world's cultures. Our question today is what can the University of Maastricht accomplish through the Hofstede Chair in Cultural Diversity, not just for the present but into the future?

My comments today will suggest some possible directions for answering the question by considering three issues. First, how has the heritage of attempts to understand culture affected the viewpoints of the audiences to which university-based culture analysts speak? This heritage includes both historical and literary treatments of culture, and treatments of culture as the various social sciences emerged. Second, how has Professor Hofstede's work framed the way culture analysts understand culture themselves? Third, what controversies that arise within the scholarly world and what practical controversies that arise in the world in general might the resources of the Chair be used to address?

\section{The Heritage of Cultural Analysis}

"Culture" has come to be combined with "diversity" as an espoused value in the United States, as, I understand, muiticuituralism has come to be advocated in Europe. Viewpoints on culture in business and in society in general bring an intellectual heritage along with them. Aspects of this heritage that add fervor to debates about culture trace back to dysfunctions in discussions of culture over the past two centuries.

\section{Late $19^{\text {th }}$ Century Culture Analysis:}

\section{Savages, Friends, Enemies, and We Ourselves}

Analyses of culture through the first half of the $19^{\text {th }}$ century show little evidence of the norm of scientific neutrality that we as scholars typically take for granted. In fact, the most careful analyses of culture 
during that period typically had the explicit purpose of justifying and supporting the virtue of the writer's own culture. Although these selfserving analyses are rarely mentioned in current social science discussions of culture, they fuifilled the same purpose of providing a basis for intercuitural understanding and interaction as do recent culture analyses. Their biases contribute to the cautiousness that many observers continue to have toward any culture analysis.

\section{Table}

Early gif Century intellectual Traditions:

sefreferential, seff-promoting culture categories

We Ourselves

our friends

Our Enemies

savages

Culture analysts in the early $19^{\text {th }}$ century constructed a world around four categories of societies - we ourselves with our distinctive strengths and quirks, the familiarly different friend, the threateningly different enemy, and the radically different savage.

\section{We ourselves}

The use of culture analysis to justify one's own soclety is reflected in Macaulay's (1848) History of England. This book is generally recognized to be the most influential history of England of the mid $19^{\text {th }}$ century. Macaulay's prologue begins by expounding on the greatness of England and reassuring his audience that his analysis will document and justify its greatness. Nevertheless, he finds it part of his duty "faithfully to record disasters mingled with triumphs, and great national crimes and follies far more humiliating than any disaster" (p. 2). Yet he remains confident in the purpose of his work, and belineves that "the general effect of this chequered (sic) narrative will be to excite thankfulness in all religious minds, and hope in the breasts of all patriots.

For the history of our country during the last hundred and sixty years is eminently the history of physical, of moral, and of intellectual improvement" (p.2). When Macaulay analyzes other societies, he contrasts them with England to point out England's superiority. Cultural histories that advocate the virtues of we ourselves is not distinctive to Great Britain, but has counterparts throughout the world. With limits, it can promote citizens' willing support for the society of which they are 
a part. It runs the risk, however, of encouraging behavior that is destructive of outsiders.

\section{Our friends}

The use of culture analysis to understand cultural friends is designed to give insight into societies similar to one's own in which one may wish to travel or have cordial business and political relationships. Such societlies are treated with magnanimity and respect, but as having interesting quirks and perhaps weaknesses. The view of cultural friends is reflected in the qualities that Jokai, a Hungarian politician, diplomat, and novellist of the mid-19 century creates for a fictitious character, Baron Leonard Hatszegi, having a heritage linked to fiwe cultures friendly to Hungary. "it was not wonderful, therefore if the noble baron possessed the qualities of five distinct races. Thus he had something of the voluptwousness of the Turk, the ostentation of the Hindu, the flightiness of the Pole, the foolhardiness of the Hungarian, and the obstinacy of the Wallach." (Jokat. $1860 / 1953$, p. 256). This particular example is more literary and suggestive than it is historical and systematic similar attempts to portray cultural friends remain evident in the Disney Corporation's attempts to communicate something about a foreign culture in ways that are appealing and non-threatening to the receiving culture (Brannen, 1992).

\section{Our enemies}

The treatment of enemies in $18^{\text {th }}$ and $19^{\text {th }}$ century culture analysis is less kind, but includes a level of understanding. For example. Macaulay contrasts English achievements in its colonial empire with the superficial and transient success that enemy spain achieved through exploiting the Aztecs and Incas. Despite hostility to enemies, even politicall adversaries in Europe were viewed as understandable in the $19^{\text {th }}$ century meaning of being civilized. Enemies however villainous had literatures, governments, and high culture. Cultural competition between England and Spain even when violent appeared against a backdrop of reasonable understanding. English virtue in contrast with Spanish villainy, in Macaulay's view, justified England's role as the umpire of Europe and provided a culturally-based ideology for animosity.

\section{Savages our servants}

Societies that technological and industrial dewelopment made powerful through the $19^{\text {th }}$ century took quite a different view of the cultures of the most dramatically less powerful societies. Sometimes, views 
expressed about such radically different societies appear to be deliberately and astonishingly inhuman. The view that non-industrial cultures were made up of savages was certainly more prevalent through the $18^{\text {th }}$ and $19^{\text {th }}$ centuries than in recent days of post colonialism and postmodernism. In the United States, slavery and the violent subjugation of native Americans were given their slim justification by treating these cultures as less valuable than cultures having a European heritage. Margaret Mead writing for the World Federation for Mental Health notes that: "Where the conquered peoples under Western jurisdiction have been considered an inferior species of humanity, legislation pro. tecting the welfare of workers has often been weak" (Mead, 1953, p. 259). The risk that culture analysis may produce this sort of dehumanization can still be evoked in audiences from parts of the world that have been most adversely affected by the colonial legacy.

\section{Unfortunate applications and reactions to $9^{\text {th }}$ century culture analysis}

The sort of self-referential culture analysis that was so important to the $19^{\text {th }}$ century intellectual climate has faded only in the face of vio. lence. Among the dysfunctions of $19^{\text {th }}$ century social thought was an intolerant glorification in some quarters of elite forms of culture. This glorification of some cultures over others supported various forms of military violence throughout the world. The sort of national pride that Macaulay supported has too often devolved into violent forms of elitism and nationalism. Similarly, in some nations, an established, powerful culture has permitted or fostered immigration by another culture or cultures. This practice has too frequently had the ultimate dysfunction of resulting in intercultural violence between the established elite and the newcomers.

Table 2

Current Popularmplications

Melting pot, cultural diversity, and political correctness in the US.

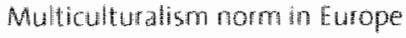

Sensitivity to risks of culture analysis

"Each person is unique"

Is the Hofstede tradinon destructive?

The thetorical rejection of this dark side of culture analysis became part of the United States heritage when matters of culture are openly discussed. Culture, at least in application to people with European 
national ancestry. came to be viewed in the United States through the "melting pot" metaphor. This reflected an ideal where everyone should be accepted as an individual rather than as a representative of their own or their ancestors' nation of origin. The implicit view was that in order to maintain harmony and to establish a new cultural identity for a nation with a large recent immigrant history, any prior cultural identity that separated one group from another was and should be lost in the larger community. As the leading source of organization studies research (Bhagat \& McQuaid, 1982), the melting pot ideal of the United states may have limited scholars' willingness to consider cultural explanations in the field.

The reason for revisiting the sadness assaciated with $19^{\text {th }}$ century cul. ture analysis and its expression in $20^{\text {th }}$ century politics is that culture scholars need to be reflective. We need to recognize this history when we speak to the world. We need to be sensitive to the damage that other culture analysts have done before, and that we have the potential to do now unless we proceed with care. We need to provide a path for unclerstanding culture that is not as self-referential as has sometimes been the case in the past. Fortunately, we have several possible paths to follow in so doing.

Two alternative purposes for culture analysis emerged as the social sciences developed from the late $19^{\text {th }}$ century into the present that successfully competed with self-serving culture analysis. One purpose was to analyze other cultures not to defend one"s own society, but to critique it. Another was to analyze other cultures in as neutral a way as possible anticipating, sometimes unrealistically, that knowledge would constructively inform societal behavior and social policy Despite a certain naiveté and lack of self-reflection, the norm of scientific neutrality strengthened in culture anallysis during the late $g^{\text {th }}$ century as it did in other fields.

\section{Emerging Scilentific Approaches to Understanding Culture}

Scholars working toward a scientific approach to culture analysis worked on three themes during the latter $19^{\text {th }}$ century. One was to develop a method for scientific, ethnographic research. A second was to work out the social implications of Darwin's theory of evolution. A third was to begin to use scientific culture analysis not to support one's own culture, but to critique it. 
Table 3

One Alternatwe: Anthropologies of Culure

Quantitative ehonography and arifacts

From Edward Tylor to Murdoch's Human Relations Area Files

Functional ethnographies.

Herbert Spencer, Malinowski, and Kluckhohn and Strodtbeck

Second Alternative: Emerging Sociology and Economics

Self-critical culture analysis

Marganet Mead

\section{Scientific anthropology}

Anthropologists began the first-hand, scientific study of culture. Their early research approaches set in motion a discussion about how quantifying cultural facts compared with providing textual descriptions of cultures as the most useful methodological basis for culture analysis. Edward Tylor (Tylor, 1871/1958) developed techniques to connect present societal practices with ancient practices by tracing a society's cultural evolution (Kardiner \& Freble, 1961). This sort of logic combining historical analysis with quantification continues in international organization studies (Gupta et al. 2002). Ethnography centered on collecting large quantities of facts. Inferences as to their meaning were drawn both through direct induction as well as through quantitatively and statistically driven induction. He also developed ways to apply new kinds of statistics like the correlation coefficient. If his cultural data indicated that two characteristics were associated across societies to a greater than random degree, he concluded that the two were causally related. He should particular interest in questions that remain central to culture theory - is there always a functional basis for cultural practices? Do cultures change as functional requirements change? Do artifacts remain of either once but no longer functional values and practices, or do the disappear? Do practices that are similar in different cultures reflect culture diffusion or parallel response to functional need?

\section{Functionalist anthropology from social Darwinism to comprehensive theories of societal functions}

A particularly influential line of scientific research about culture was the adaptation of theories of evolution to social situations. The theory of biological evolution was a central theme in all areas of social thought during the later $19^{\text {th }}$ century. Herbert Spencer published a series of cultural analyses taking a view advocating unfettered competition in 
all areas of life justified by generalizing evolutionary theory to social processes. Spencer used an evolutionary logic to justify the position that government regulation impeded competition and thus worked against the evolution of socially adaptive cultural practices (Kardiner \& Preble, 1961; Spencer, $1885 / 1893$. e.g. pp. 575-589). In his view, all people and all societies are fundamentally alike in that societies adhere because they give a survival advantage to individuals who choose to become part of societies over those who remain isolated. The particular qualities of societies, epitomized by technologically advanced societies, reflect adaptive advantages. His work substantially influenced a large popular audience. Spencer reported evaluations of his view against a large quantity of facts that he had assembled, and claimed that he was following an inductive method, a claim subsequently criticized by most commentators.

Bronislaw Malinowski's (1922/1965) field research documenting the Trobiand Islanders shared an interest in functions with anthropologists interested in evolution. However, it remained more strictly scientific rather than becoming linked to social and political agendas associated with promoting competition between people and societies. His dedication to field work whille living in primitive societies has been rarely imitated. Malinowski $(1939 / 1944)$ structures the debate about whether culture practices are always constructive rather than being artifacts of past practice by developing what has come to he called a functional view of culture. He proposes five axioms of functionalism:

A. Culture is essentially an instrumental apparatus...

B. It is a system of objects, activities, and attitudes in which every part exists as a means to an end.

C. It is an integral in which the various elements are interdependent.

D. Such activities, attitudes and objects are organized around important and vital tasks into institutions...

E. From the dynamic point of view, that is, as regards the type of activity, culture can be analyzed into a number of aspects... (p. 150).

Kluckhohn and Strodtbeck (1961) developed a particular functional view in anthropology that has been drawn on by other disciplines and is continuing to appear in organization studies. Their view depended on the quantitative study of values beginning from a functional base and using the aggregated self-reports of a society's members. The use of selfreports had become part and parcel of anthropological field methods, but 
the use of structured interviews to collect that kind of information, the application of statistics to help interpret them, and the appeal to universal dimensions of values rooted in functional necessities faced by al! societies were more innovative. Florence Kluckhohn had been deweloping a functional theory of values during the 1940 s that provided the basis for fieldwork in the Rimrock area of New Mexico during the early 19505.

The theory as refined based on the field project suggested that all human groups face five problems that can be viewed as either questions that the society must answer or value orientations that reflect the basic nature of the society's answer. These are:

(1) What is the character of innate human nature? (human nature orientation)

(2) What is the relation of man to nature (and supernature)? (man-nature orientation)

(3) What is the temporal focus of human life? (time orientation)

(4) What is the modality of human activity? (activity orientation)

(5) What is the modality of man's relationship to other men? (relational orientation)" (Kluckhohn \& Strodtbeck, 1961, p. 11).

\section{Critical anthropology}

A third theme that shaped cultural anthropology early in the $20^{\text {th }}$ century was the increase in the critical spirit over either the justification of one's own society or the application of evolution. While the collection of information continued in cultural anthropology. using data to support any particular theory became quite secondary to societal selfreflection for a number of influential scholars (Kardiner \& Preble, 1961). Franz Boas wrote a forward to Margaret Mead's Coming of Age in Samoo (1928/1949) that reveals the critical spirit that he adopted and encouraged students like Mead to take. He argued that although comparative ethnography may provide some scientific opportunity to learm about societal development patterns, it more importantly reveals the relativity of practices taken for granted in one's own sociely. No longer is culture analysis directed toward justifying one's own society, but rather toward critiquing it.

Mead's argument, for example, that the struggles of adolescents in Samoa are radically different from those of their counterparts in Euro- 
pean and American society is intended to make the point that the func tionaluy of social processes are highly contingent on cultural context. Mead's feld work beginning in the 1920 s documented the practics in primitive societies as extensively as had any published to the time. Both her method of relying on text rather than collectons of facts to report her results and the culturaly self-critical use that she made of herconclusions were imitated by many others. In international orgamiation studies, the critical spirit appears when the apparent succes 5 of busimess practices in any particular part of the world provides the basis to critique or reconsider practices in one's own society. Kluckhohn and strodtbeck $(1961,0.1)$ note that this critical approach in anthropology helped to overcome universalistic views of people and societies.

\section{Systematic comparative anthropology}

A major continuing project in anthropology combines the scientific interest in accumulating and analyzing cultural facts with a functional view of cuture, while generally de emphasizing either the evolutionary or critical agendas. The Cross-Cultural Survey (Murdock, 1940; 1967, 1981) was developed during the 19305 as a means to systematize the accumu lating series of fragmented ethnographies by cultural anthropologists throughout the world. The problem it sought to solve was the surfeit of riches - the growing accumulation of descriptive cultural naterial without a means for social scientists, particularly non-anthropologists. to sort through it. The Survey was not a "survey" in the current sense of a paper-and-pencil or interview document to which participants respond instead, it was a stuctured scheme for coding anthropological field data The project continues to seek to assemble and code all anthropolog:cal materials about given culture, ancient or modern, in a way that provides access to details and promotes comparison. "It is organized so as to make possible the formulation and varification (sic), on a large scale and by quantitative methods, of scientific generalizations of a universaly human or cross-culturat character. Sociologists and most other social scientists regard the establishment of generalizations or 'laws;' ie. veri. fied statements of correlations between phenomena, as their primary aim, but anthropologists tend to shy away from theory, as Kuckhohn has pointed out, and to confine themselves to historical rather than sci. entific interpretations of their subject matter...

The plan rests, at bottom, on the conviction that all human cultures. despite their diversity, have fundamentally a great deal in common. 
and that these common aspects are susceptible to scientific analysis" (Murdock, 1940, p. 364). In so saying. Murdock identifies himself with those functionalists in anthropology who believe that the critical viewpoint had adopted an ideological social critique purpose that worked against accumulating scientific knowledge about culture. The methods Murdock proposed that anthropologists follow take four steps: formulating hypotheses, quantitative verification across large numbers of cutures, critical analysis from the stand point of warious cultural areas, and detailed examination of exceptions to seek countervailing explanations in other wariables. These are very much the sort of scientific steps that are consistent with most international organizational studies. Although the project's principal coding tends to focus on societal characteristics that have limited organizational studies relevance farchitectural styles, for example) and on societies that havelittle contact with modern orga. nizations, the maps of ethnographic materials may provide the basis for organizational scholars to access material about societies of particular interest (Burton \& White, 1987 ).

\section{Anthropology's contributions to international organization studies}

Each of these approaches to anthropology continues to affect organizational studies scholarship. For example, the use of an anthropological account of a different context in order to critique one's own continues in the case analysis approach to teaching management. Ethnographic analyses also sometimes identify a new concept or a nuance on an established concept that has not been previously represented. However, the approaches to cultural anthropology that have most substantially influenced international organizational studies have a functional base. The sets problems proposed in such approaches have provided a sufficient theory base to provide points of connection to organizational theories developed from psychology and sociology.

\section{Culture in Emerging Sociology and Economics}

Anthropology took the analysis of culture as its own special domain. Nevertheless, sociology and economics at the turn of the $20^{\text {th }}$ century also dealt with culture as at least a side theme in their task of analyzing the universals of the human condition.

Weber's (1947) theory of social and economic organization is an analysis of culture change, culture generality, and culture differences. His early studies of those ancient near eastern societies from which 
modern western cultures drew most heavily and his general historical approach to analysis provided a culture change perspective. His analysis of Western civilization as a discrete entity rather than a set of separate nations supports organization scholarship to document the business significance of multi-nation cultural regions. His study of the religious heritage of China, India, and Western societies provides a distinctive comparative viewpoint. Rather than insisting on the radical uniqueness of social constructs peculiar to particular societies, Weber linked a culture's idiosyncrasies to more generalized concepts, notably ideal types of socioeconomic systems, that permitted comparison.

\section{Table 4}

Sociology and Economics

Cultural versus structural imperatives -.. Weber and Marx

Mir study of economic developrnent and industrialization

"Industrialization has a commanding logic of its own ( $p .6)$.

"The increasing convergence of advanced industrial states is a long run tendency.

A project conducted through MIT beginning shortly after WWII took Weber's socio-economic theme further by providing an analysis of the interplay between economics and cultural sociology (Harbison \& Myers, 1959). Dunlop. Harbison, Kerr and Myers (1975) summarize the results of a 25 year project conducted at MIT that has substantially influenced both the U.5. government and international organizations like the World Bank and United Nations in efforts to promote economic development and industrialization. They summarize their conclusions around twelve main themes, several of which bear on the issue of whether culture shapes industrialization or the reverse. As examples, two of these emphasize the social force of industrialization:

"Industrialization has a commanding logic of its own (p. 6).

"The adaptability of labor and the evolutionary character of most workers' movements ease the industrialization process. (p. 15) Also as examples, three others emphasize the social force of societal cullure:

"Many countries face barriers to industrialization and industrialization has its costs. (p. 10)

"The increasing convergence of advanced industrial states is a longirun tendency, $(p, 11)$

"The world lives by values as well as by analyses." (p. 12) 
These sorts of general conclusions about the effects of economic development are often criticized as ethnocentric and this group of scholars is often thought to have overestimated the influence of industrialization as a global homogenizing force. Nevertheless, this project was part of the stimulus for debates about whether globalization both in business and more generally in society is occurring and should continue to occur.

Analyses that jointly consider economics, sociology and culture continue to influence the policy of governments and non-governmental organizations (NCOS). For example, an early post-WWII manual about simultaneously promoting mental health and technological development was prepared by the World Federation of Mental Health and edited by Margaret Mead (1953). The goal of their project was to recommend how government and business leaders can introduce technical change so as to minimize broad societal disfuptions. The report provides examples of dysfunctions that technological change and monetary economies have had in a range of societies - Greece, Navaho, China, for example. In the context of the contrast of modern technology and economics with traditional tribal life and village agriculture, the debate about whether modernization creates convergence is a debate about the situations in specific examples like these three. However, when viewed from the standpoint of differences among current nation states in parts of the world with substantially different cultural traditions, the specifics are seen as linked to major global conflicts and changes.

\section{Culture Analysis at the Time of}

\section{Early International Organizational Studies Research}

The MIT project coincides with the historical edge of other efforts to incorporate cultural considerations into organization studies. During the 1960 s and 19705, international organizational studies began to emerge as distinct from the sort of international economics represented by the MIT project. The two component fields of organizational studies are psychologically-based organizational behavior and sociologically-based organizational theory. The organizational behavior literature in the 19605 and 1970 s included a substantial number of questionnaire survey studies about a broad range of employee perceptions, beliefs, and attitudes. The organization theory side of the field centered around systems theory and structural contingency theory. Both occasionally evidenced selective use of or reaction to issues in the international sociology and anthropology literatures. At the same time, approaches to the study of 
values were developing out of anthropology, psychology and sociology that, while not immediately integrated into the organizational studies iterature, would also shape the research that would follow.

\section{Table 5}

Third Alternative: Psychology and Organization Studies

Scattered cultural studies in organizational behavior
- Roberts (1970), Bhagat and McQuaid (1982)
Scattered cultural studies in organization theory and design - Child (1981)
A functional integration of scattered "national character" studies in psychology
-inkeles and Levinson (1954/1969)

Several reviews identified major weaknesses in the way culture was treated in the international organization studies literature. Roberts (1970) reviews several hundred international organizational behavior studies conducted through the 1960 s. She frames her review by criticizing the fragmented and poorly articulated way in which culture theory was being handled, and the methods by which research was being conducted. For example, she notes that the literature was fragmented by discipline and that the particulars of this fragmentation are not unique to international organizational behavior, but reflected a larger fragmentation in the social sciences. She also notes that the literature reflected disproportionate influence of scholars from the United States. Punnett and Ronen (1984; Ronen, 1986) reviewed 34 of the larger internationall comparative organizational behavior studies published during the 1970 . The preponderance of research attention was devoted to identifying mean differences in work goals or values between respondents from different nations. In particular, a number of scholars were interested to understand whether McClelland's (1961) research providing a motivational basis for national differences in overall economic development could be replicated with attitude survey methods or were reflected in organizations. Others were interested in whether the sorts of needs that Maslow (1954) had postulated and associated work goals that were being increasingly used as a basis for informing enlightened manage. ment practice differed among nations. When differences were identified, explanations were typically sought in industrialization and related variables like education and GNP or in traditional variables like religion and language. A few studies were concerned not with mean differences in attitudes, but in whether the relationship between attitudes and criteria varied by nation. That is, does the success of managers depend on 
the values they hold, and do such relationships differ by nation $(B$ ass \& Burger, 1979; England \& Lee, 1974)?

The situation was similar in the sociological side of international organization studies, although the quantity of research was more limited. Child (1981) argued that orgamization design research had neglected the influence of cultural variability as well as the pressures common to capitalist systems in their focus on studies about the appropriate fit between particular organization designs and contingencies like the size, environment, and technology of organizations. He noted the possibility of functional equivalents - that different culturally unique ways may be found to handle problems of large scale work organizations.

Perhaps the most influential international organizational research project during this period illustrates the motives affecting scholars at the time, the theories and methods from which they drew, and the way in which they were conducted reflected issues of the day and earlier research traditions. Haire, Chisell and Porter (1966) were interested in "(1) The opportunity to examine and understand managerial attitudes in one"s own country: (2) the implications for firms sending managers to work in foreign climates; and (3) the problems of executive development across cultures." (p. 13). These interests were part of the process of accom. modating the expansion of U.S. foreign investment following WWII. U.S. multinationall management practice of the day included extensive use of U.S. nationals sent overseas. Expatriates needed to be selected and prepared for their assignments. Haire, Ghiselli and Porter's project was designed to help organizations handle this need. The substance of their research reflected a widespread scholarly interest in participative management practice at the time. They identified an apparent paradox, possibly between icleals and perceived reality, about the ordinary person's capacity for participation in significant decision making. The general finding was that whereas managers regardless of nationality support the value of participation as an ideal, they generally seem to bellieve that most people are neither interested in nor particularly capable of participating in making significant organizational decisions.

Their project has made some enduring contributions. It used survey data to compare attitudes and assumptions about managerial practices, descriptions of managerial roles, and managerial motivations in 14 nations. In so doing, they take a highly scientific view of analyzing 
organizations. They express "the conviction that only the most precise and quantifiable knowledge possible is knowledge in the proper sense" (p. v). Their approach to translation and checking translation accuracy through backtranslation showed a sensitivity to the limitations in transferring scientific ideas from one nation to another that reappears in comparative questionnaire research through the present. In particular, they explain the limitations in translating some words used frequently in organizational studies like "leader" and "team." They also introduce the idea of clusters of similar cultures by showing meaningful similarity with sets of nations: Nordic European (Norway, Denmark, Cermany and Sweden), Latin European (France, Spain, Italy and Belgium), Anglo American (U.S., Britain), Developing Countries (Argentina, Chile, Italy). and Japan. They show sensitivity to regional variability by noting that their two Belgian samples varied in ways that located one somewhat closer to Nordic Europe than the other. These clusters of nations contributed to debates of the day by suggesting that language and technological development were not the overwhelming determinants of culture.

The project's main limitation was one shared with all other international organization theory research of the day. It lacked a theory of cultural differences between nations to organize previous observations, structure subsequent predictions, and guide applications.

\section{Opportunities for Grounding International Comparative Research: Values and National Character}

International organization studies had not found a theoretical basis to integrate the accumulating, number of international comparative studies or guide their further development, but some alternative possibilities were becoming available. One alternative for analyzing culture presented itself was the psychological study of values, an area of research that was convivial to the interest of organizational behavior scholars in working from questionnaire surveys. The study of culture had firmly become the domain of anthropology. but the study of values had become part of the language of psychology as well. Rokeach (1973) worked toward the idea of values from a psychological base, but one that was informed by the functional anthropology of kluckhohn and Strodtbeck. Like Kluckhohn and Strodtbeck, Rokeach took the position that all societies faced similar functional requirements. These requirements produced what he called terminal values. Due to historical and situational uniquenesses, each society developed quite varied ways of 
pursuing these terminal values. Once institutionalized within a society. these were experienced as equally necessary by the society's members. However, due to their variability from one society to another, an observer could recognize that these were secondary instrumental values. The language of values became central to the eventual formulation of international organization studies, although the Rokeach project was just one element of the values frameworks that became influential.

A second alternative for integrating international organization studles was provided by Inkeles and levinson $(1954 / 1969)$. They offered a careful review of anthropological and psychological research into what was then called national character beginning with literature from early in the zoth century. Within anthropology, they note the divergence that had developed between scholars like Franz Boas and Margaret Mead who took a society-specific approach to culture analysis and those like Kluckhohn and strodtbeck who took a functional approach. They also describe the several lines of psychology that had been influential in culture analysis, notably Freudian psychology, learning theory, and two holistic theories -- Gestalt psychology and field theory. They note that Freudian psychology had stayed largely in the realm of psychotherapeutic practice and had not been integrated scientific psychology in general let alone into comparative culture research. Learning theory, in their view, had taken on a universal quality by focusing on common human learning characteristics. By the time of their review, Mcclelland (1961) had published an influentia! study of culture differences that appeared to predict economic development. The method taken in the study was to code children's books to identify imagery indicating a need for achievement. Although the specifics of the study's conclusions have been questioned, it had the enduring effect of directing attention to the idea of need for achievement, encouraging the search for aspects of culture that may be linked to economic development, and suggesting that supporting the view that not just individual socialization as a child, but socialization patterns in a sociely may have society-wide and international implications. Inkeles and Levinson (1954/1969) devote a considerable part of their review to comparative studies of child raising and socialization likely to have societal implications.

The Inkeles and Levinson review offered an opportunity to solve the problem of fragmentation that reviewers of international organization studies research had noted by providing order to the base disciplines. 
of anthropology and psychology. The upshot of their analysis was that values research had the most promise, but the promise had not been realized. Work up to the time of their review had been too focused on narrow topics rather than representing the full range of values and had dealt with too few countries or societies. They proposed that advancing the comparative study of culture required attention to a set of "standard analytic issues." These were: (1) "relation to authority." (2) "conception of self," and (3) "primary dilemmas or conflicts, and ways of dealing with them." These issues have the same quality of identifying societal problems or social functions that Kluckhohn and Strodtbeck (1961) and Murdock (1940) had introduced. Psychological research that appeals to values and anthropological research that identifies functions has, as Inkeles and Levinson suggested, ultimately came to be at forefront of subsequent comparative culture research. This did not immediately occur, however, when Inkeles and tevinson first published their review in 1954 or when they republished it in 1969 .

\section{The Status of Comparative Values Research at the End of the 1970s}

By the end of the 19705, the status of comparative arganizational studies research was uncertain. Harbison and Myers" (1959) research continued to inspire consideration of the possibility that optimal management practices were culturally contingent. Bass, and Burger (1979) had followed up on Haire Ghiselli and Porter"s (1966) topic of identifying differences in the sort of attitudes that expatriates should have and the leadership approaches they should use in different nations. Comparative studies of participation continued with a study of the effects of legislaw tion promoting "Industrial Democracy in Europe" (IDE, 1981) and with research by Heller and Wilpert (1981) about the nature and correlates of participative decision making in various parts of the world. Neither Kluckhohn and Strodtbeck nor Inkeles and Levinson followed up on their own ideas in ways that had the influence of their earlier publications. Several scholars began to use the Rokeach values Survey in multiple countries. The global landscape also changed outside of social science academe. Competition of the United States and European mations with Japan and the rapidly developing nations in Asla directed attention to the potential business relevance of even larger apparent differences in culture than those between the U.S. and Europe that stimulated earlier interest. Horstede's (1980/200i) book Culture's consequences entered the field by providing a set of scores for many countries on dimensions of national cultural values that were linked to a general functional theory. 


\section{Enter Culture's Consequences and Geert Hofstede}

oceasionally in social science, a single project or single researcher will be the central focus of a field for a period of time. Hofstede's project. summarized in Culture's Consequences (Hofstede, 1980, 2001) has dominated international organization studies since its appearance Some dynamics in the field of management stimulated by Hofstede's work were due to particular choices he made about what to disseminate and how to disseminate it. He provided culture scores for 53 countries. This is in contrast to quite a number of other lines of culture research and theory. Kluckhohr and Strodtbeck (1961), for example, did not collect data from multiple nations, so their work could only be used conceptually for international comparative analysis. Without scores that can be linked to particular societies, other work like theirs provided interesting ideas to consider, but little way to link them to any particular setting in which a researcher is working. Not until Culture's Consequences did the field have national culture data spanning a large proportion of the globe.

\section{Perspectives on values, culture, and research methods}

Hofstede begins by providing a conceptualization of culture and addressing a variety of issues in studying culture, both in general and as applied to his own project. In a distinctly appropriate definition for a study based on data from a computer company, Hofstede defines culture as "the collective programming of the mind that distinguishes the members of one group or category of people from another" (2001, p. 9 ). Some universal programming, such as the capacity for language and the basic nature of emotions, is shared among all people as a consequence of genetic makeup. Collective programming, such as the content of particular languages and the forms of emational expression most typical or acceptable in particular societies, is characteristic of particular groups or categories of people. Indiwidual programming, such as the unique ways that a particular person uses language or expresses emotion, is a consequence of personal makeup and experience. Hofstede's project focuses on collective programming, particularly in groups defined by national boundaries. Nattional cultures may be reflected in typical personality characteristics, what was labeled "national character" during the mid$20^{\text {th }}$ century, but includes societal characteristics as such in addition to typical personal characteristics.

While recognizing a variety of ways in which collective programming is expressed. Hofstede chooses to focus on its expression in val- 
ues. Values are "a broad tendency to prefer certain states of affairs over others" (p. .5). In using this definition, Values have intensity in the sense of strength and direction in the sense that some states of affairs are viewed as preferable to others. Values for what is desirable for people in general can also differ from those about what is desired personally. Values can be expressed in three types of practices - symbols, heroes, and rituals. The meaning of each in a given culture is based on the link of a particular practice to the value that it expresses. Displaying the color red, for example, has different symbolic meanings due to its link to different values in various countries. In providing this analysis. Hofstede appealed to similar uses by one anthropologist and one psychologist - Kluckhohn and Rokeach.

Hofstede argues that national cultures have origims and a set of reinforcing dynamics that give them considerable stability. The gradually evolving, mutually reinforcing system that tends to define as society includes ecological factors such as geography and history, the society's norms, and the structure and functioning of social institutions like family, roles, political systems, and religions. Despite the stabilization that these reinforcing factors provide, cultural change is certainly possible through the intervention of outside forces through trade, domination and the diffusion of scientific discoveries.

Hofstede's way of solving the problems of giving a structure to culture analysis in international organization studies was not without methodological issues to face. One that has been especially pernicious is the problem of level of analysis. Relationships among variables based on questions asked of individuals (individual correlations) often differ from relationships among variables based on societal averages of individuals" answers (ecological correlations). An ecologicall fallacy is committed when ecological correlations are interpreted as though they were individual correlations. For example, on recent criticism of Hof stede's research was that his measures of culture dimensions were not reliable (Spector, Cooper \& Spark5, 2001). Instead of taking the national averages of the items used to form the culture dimension measures. the critics calculated reliability coefficients based on the individual level scores and assumed that these reliability coefficients reflected the reliability of the national averages. Doing research at the level of nation requires that a sufficient number of nations be studied. The number of projects that include multiple nations continues to increase. 


\section{Culture Consequences: Transforming Culture Debates}

its subsequent widlespread use indicates that Culture's Consequences provided the integrative theory that international organization studies had lacked. It did so by identifying a taxonomy for understanding culture and linking that taxonomy to an established theory of social functions. It provided enough theoretical insight into the nature of the culture dimensions to use them to make predictions about how they would relate to other social phenomena. Although the focus was on consequences rather than antecedents, it also provided preliminary analysis of the possible origins of national cultures. The field of international organization studies subsequently either applied this theoretical frame to particular topics, or offered critiques and alternatives to this frame. Whether by use or by critique, the field continues to be structured by Hofstede's theory.

Table 6

How culture"s consequences frames current culture anaysis

Culture analysis in international organization studies is now -.

Largely separated from cultural self-justification or critique

linked to social functions

Expressed in configurations of typical walues, attitudes and beliefs

Expressed (at least in part) by surweys

Culture analysis in international organization studies following Culture's Consequences is now more closely allied to some traditions in anthropology than others. It is largely separated from either the sort of cultural self-justification typical of $19^{\text {th }}$ century analysis, or the use of culture analysis for self-critique more typical in the $20^{\text {th }}$ century. Instead. it culture analysis has a scientific orientation that is linked to a view of social functions stimulated by Inkeles and Levinson"s (195.4/1969) integration of culture literatures in psychology and anthropology Organization scholars continue to treat culture as being about configurations of values, although the specifics about what values should be studied are debated The language of societal patterns in mental pro. grams is beginning to be replaced by language from the psychology of cognition or the sociology of institutions, but the theoretical structure remains the same. Culture provides the social substrate, the "programs" that individuals use to interpret their experience culture is also something that can be inferred in some way from surveys administered to individuals, although considerable confusion and difference of views 
remains in the composition rules that link individual survey responses to societal characteristics.

\section{Table 7}

What can the Hofstede Chair be wsed to accomplish?

Possiblitites:

1. Clarify individual links to societal cultures

2. Improve culture representations

3. Flesh out numbers with qualitative ethrographes

4. Reconsider cultural boundaries

5. Model intercultural dynamics

6. Better represent understudied locales

\section{Purposes for the Hofstede Chair in Cultural Diversity}

The resources of the Hofstede Chair in Culture Diversity have the potential to be used to take international organization studies in directions that build on what has been accomplished in intermational organization studies to this point in time. Some of these are to find new ways to overcome misunderstandings that continue to arise in culture theory. Others are to take culture theory into new areas.

One possible purpose is to continue to clarify the links between individuals and societal cultures. Accomplishing some of this purpose requires restating arguments that have already been made, but that continue to generate misunderstanding . For example, the dimensions reported in Culture's Consequences are characteristics of societies, not of individuals. is a person who says that they are "afraid to disagree with their managers" a large power distance person? No. Is the person who expresses this fear likely to be part of a system where managers face the temptation to be exploitive and where many subordinates cannot escape? Yes. Culture characteristics most directly shape what people expect will happen or what they will find normal, but will have only a loser link to personal attitudes about what they typically experience.

A second possible purpose is to participate in continuing discussions about representing societal cultures based on configurations of values. Alternatives to the dimensions proposed in cuitures consequences have been developed. and their comparative advantages and limitations require continued reflection. Among the more prominent recent 
examples are the individual and national dimensions drawn from the Schwartz Value Survey (Schwartz, 1994), the World Values Survey (Inglehart, et al., 1998), and the Global Leadership and Organizational Behavior Effectiveness project (House et al., 2004).

A third possible purpose of the chair would be to promote the use of qualitative ethnographies to prowide greater depth in culture analysis than is provided by scores derived from surveys. Whereas, culture dimensions may show the societal equivalent of north, south, east and west in a way that helps one become oriented, they are highly incomplete.

A fourth purpose is to refine and otherwise reconsider cultural boundaries. Nation states have been a highly influential social intervention. particular in the past two centuries. However, sets of nations, withinnation regions, and globally-linked ethnic communities all have the potential to have cultural significance. As social indicator data sets become more ellaborate, the opportunity for providing cultural information is increasing for both mations left out of prior projects, and for other cultural regions besides nations.

A fifth possible direction is to seek to model intercultural dynamics at different levels. At the most macro level, such work could be directed toward predicting how interactions between nations will unfold and perhaps offering political leaders with ideas about possible constructive ways of intervening. Similarly, it could consider whether and how societal institutions will diffuse or whether and how globalization will prog. ress. Large scale intercultural dynamics are also part of immigration. At the level of individuals, since culture shapes what individuals will find normal, it will influence what they find unexpected when interacting with individuals from societies different from their own.

A sixth possible direction is to continue the sort of initiatives reported in the 2001 edition of Culture's Consequences to provide information about understudied parts of the world. For example, cultural information about Afica, central Europe, eastern Europe, and the Middle East may need extension and validation. 


\section{Conclusions}

Establishing a Chair in Cultural Diversity at the University of Maastricht and evoking the tradition of culture analysis that Professor Hofstede"s project stimulated has the potential to continue an already substantial contribution. I much appreciate the opportunity to be part of this effort.

\section{References}

Bass, B.M. \& Burger, P.C. (1979). Assessment of managers: An international comparison. New York: Free Press.

Bhagat, R, 5. \& McQuaid, S.f. (1982). Role of subjective culture in organizations: A review and direction for future research. Joumal of Applied Psychology Monograph. 67(5), 635-385.

Brannen. M.Y. (1992). "Bwana Mickey": Constructing Cultural Consumption at Tokyo Disneyland In Joseph I. Tabin (ed.). Re-Made in Japan. New Havern: Vale University.

Burton, M.L. \& White, D.R. (1987). Cross-cultunal surveys today Annual Review of Anthropology, $16,143-160$.

Child, 1. (1981). Culture, contingency, and capitalism in the cross-national study of organizations. Research in Organizational Behavior, 3, 303-356. Creenwich, $\mathrm{CT}$ JAI Press.

Dunlop, I.T. Harbison, F.H., Kerr. C. \& Myers, C.A. (1975). Industriahism and industrial man reconsidered. Princeton, N.J.. Inter-University Study of Human Resources in National Development.

England, GW \& Lee, R. (1974). The relationship between managerial values and managerial success in the United States, Japan, India, and Australia, Joumal of Applied Psychology, $59(4), 411-419$.

Gupta, V., Hanges, P., \& Dorfman, PW. (2002). Cultural clusters: Methodology and findings. Journal of World Business, 37, 16-27.

Haire, M. Ghiselli, E.F \& Porter, L.W. (1966). Managerial thinking An international study. New York: Wiley.

Harbison, F. \& Myers, CA. (1959). Management in the industrial world New York. McGraw.Hill.

Heller, F.A. \& Wil pert. B. (1981) Competence and power in manageval decision-making: A study of senior-levels of organization in eight countries. London: Wiley.

Hofstede, C. (1980/2001). Cultures consequences: fnternational differences in workrelated walues, and ed. Beverly Hills, CA: Sage.

House, R. I. Hanges, P.., Javidan, M. Dorfman, P.W., Gupta, V and 170 co-authors (2004). Leadership and Organizations: A 62 Mation GLOBE Study. Thousand Oaks. CA: Sage.

IDE International Research Group (1981). Industrial Democracy in Europe. Oxford: Oxford University Press.

inglehart et al. (1998). Human Values and Bellefs: A Cross.Cultural 5ourcebook: Political, Religious, Sexual, and Economic Narms in 43 societies: Finding from the 
$1990-1993$ World Wolues Survey. Ann Arbor: The University OH Whichigan Press.

inkeles. A d Levinson, D.J. (1954/1969). National character: The study of modal per-

sonality and sociocultural systems. In G. Lindrey \& E. Aronson, eds. The hand-

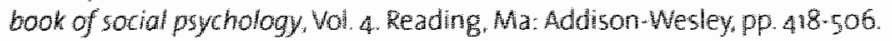

Joka M. (1860/1953). Poor plutocrats. New York Collier \& Sons.

kardiner, A, \& Preble, E. (1961). They studied man. New York. World.

Kuckhohn, F.R. \& Strodtbeck. FL. (7961). Variations in walke orientations. Evanston. 1L. Sow, Peterson.

Macaulay. Thomas 8. (1848/5962). Macaulay's History of Englond London: Dent, Everyman's libralry.

Mallinowsh, B. 1939/944. The functional theory in A scientific theory of culture and other essays chape Hill: University of North Carolna Press.

Malinowsh, B. (1922/1965). Sol tilling and agricultural rites in the Trobriond islands. Bloomington: Indiana Uniwersity Press.

Maslow A.H. (1954). Motiwation and personality New York. Harper \& Row.

Mcclelland, DC, (1961). The achieving society Princeton: Van Nostrand Reinhold.

Mead. Margaret (ed., 1953). Cultural patterns and technical change. New York: UNESCO.

Mead. M. (1928/1949). Coming of age in Samoa. New York. Morrow.

Murdock George P. (1990). The cross cultural survey. American Sociologicai Review. 3. $361-370$.

Murdock, Geonge P (1967). Ethnographic atlas. Pittsbungh: University of Pittsburgh press.

Murdock, George P (1981). Allas of world cultures. Pittsbugh: University of Pitsbutgh press.

Punnet, B.1. \& Ronen, S (1984). Operationalizing cross-cultural variables. Paper presented at the forty-fourth annual meeting of the Academy of Management. Boston, MA, August 1984.

Roberts, K.H. (1970). On looking at an elephant: An evaluattion of cross-cultural research related to organizations. PSychological Bulletim, $74.327-350$.

Rokeach. M. (1973). The nature of human values. New vork: Free Pres. $5 p .3-52$.

Schwartz, 5.H. (1994). Cultural dimensions of walues: Towards an understanding of national differences. In U. Kim, H.C. Trandis. C. Kagitçibas: S.C. Chor \& C. Yoon (Eds). Indiwdualism and collectivism: Theory, methad and applications (pp. 85. 119. Newbury Park, CA: Sage

Spector, PE., Cooper, C.L. \& Spaks. K (2001) An international study of the psychometric properties of the Hofstede Values Suney Module 1994: A compa. rison of individual and country/province level results. Appled Psychology: An Intermational Review, $50,269-28 \%$.

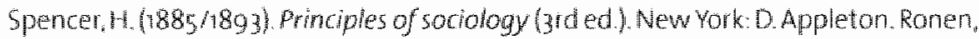
5. (1986). Comparative and multinational management. New York Whley.

Tylor E (1871/1958). Primitive culture. New York: Harper.

Weber $M$. (1947). The theory of sociat and economic organization (T. Barsons, ed.). New York: Free Press. 
